\title{
WHAT IS WRONG WITH POPULISM?
}

\author{
Enes Kulenović \\ Faculty of Political Science \\ University of Zagreb \\ E-mail: enes.kulenovic@fpzg.hr
}

https://doi.org/10.20901/an.18.14

Review Article

Received: October $21^{\text {st }} 2021$

Accepted: November $5^{\text {th }} 2021$

\begin{abstract}
The main goal of this article is to explore the relationship between populism and representative democracy. The paper is divided into two parts. In the first part, the paper offers a detailed analysis of the three criticisms of populism and the implications these criticisms have on our understanding of representative democracy. First, it addresses the argument that populism inevitably relies on demagogy and it examines the inference this argument has on the concept of political representation in democracy. Second, it discusses the claim that populism relies on the oversimplification of political issues and what this claim reveals about the democratic ideal of the informed and politically responsible voter. The third criticism deals with the anti-pluralist character of populist politics, which, the paper argues, can also be extended to the concept of popular sovereignty itself. In the second part, the article looks more closely at the relationship between populism and representative democracy. Relying on the insights from the first part, it examines different institutional restraints on the will of the majority and how populism redefines these restraints as anti-democratic and elitist barriers to popular will. Finally, the paper questions the prevailing view that sees populism as a phenomenon arising from the tension between liberal and democratic principles within representative democracy and offers an alternative framework for understanding the relationship between populism and democracy.
\end{abstract}

Key words populism, representative democracy, demagoguery, popular sovereignty, the people

\section{Introduction}

Political theorists' recent interest in the topic of populism focuses mainly on two questions: 1) What is populism? i.e. the definition of the concept of populism itself and 2) What is the moral character of populism? i.e. should we understand populism as a negative or a positive political phenomenon.

Definitions of populism range from Cas Mudde's and Cristoval Rovira Kaltwasser's understanding of "populism as a thin-centered ideology" (Mudde and Kaltwaser, 2017: 6), and John Judis arguing that populism is "not an ideology, but a political logic" (Judis, 2016: 11), Michael Kazin calling it a form of political "language" (Kazin, 1995: 1) to Ernesto Laclau talking about populism as a rhetoric and "mode of articulation" (Laclau, 2005b: 34). Although there is no consensus among contemporary political theorists on the definition of populism, two elements seem to play an essential role in most characterizations of populist politics: criticism of the elites and the populists' claim that they represent the true interests of the people (Mudde and Kaltwaser, 2017; Judis, 2016; Müller, 2016). 
Answers to the second question - What is the moral character of populism? - are wide-ranging. On the one end, there are authors who look at populist politics only in negative terms. For Jan Werner Müller populism represents "a degraded form of democracy" (Müller, 2016: 11), while Pierre Rosanvallon talks about populism as "a perverse inversion of the ideals and procedures of representative democracy" (Rosanvallon, 2008: 265). On the other end, there are influential thinkers who look at populism in much more favorable light. Ernesto Laclau goes as far as calling populism an essence of politics and an idea that leads to democratization of democracy (Laclau and Mouffe, 1985, Laclau, 2005a). Similarly, Christopher Lasch argues that populism is an "authentic voice of democracy" (Lasch, 1996: 106). Most authors, however, fall somewhere in the middle, pointing out both the negative and the positive aspects of populist politics and maintaining that "populism can work as either a threat to or a corrective for democracy" (Mudde and Kaltwaser, 2017: 76). ${ }^{1}$

The focus of this article somewhat departs from the questions of definition and moral character of populism that dominate contemporary debates by asking the following question: what can populism reveal about the nature of democracy itself? By posing this question, I follow Margaret Canovan who understands populism primarily as a response to certain ambiguities that arise from democratic rule or, as she puts it, looking at populism as a "shadow cast by democracy" (Canovan, 1999: 3). However, I want to take her line of argument a step further and argue that populism dispels certain core presuppositions that define our understanding of the nature of representative democracy. Canovan's task is Tocquevillean in nature: it takes into account the complex relationship that exists between the good and the bad sides of democracy. To put it in another way, Canovan points out how certain faults in the character of the democratic Dr. Jekyll can lead to the rise of the populist Mr. Hyde. I, on the other hand, want to be a bit more dramatic and point out that, in fact, Dr. Jekyll and Mr. Hyde are the same person all along. To achieve this, I will begin by asking the question: what is it that we find so disturbing about populist politics - or: What is wrong with populism? The central argument developed in this article is that by looking at some of the main problems that arise from the populist agenda, we can get a deeper insight into challenges facing representative democracy itself. In short, answering the question 'What is wrong with populism?' also reveals what is wrong with representative democracy.

The paper is divided into two parts. In the first part I look at three criticism of populism and the implications these criticisms have on our understanding of representative democracy. First, I address the argument that populism inevitably relies on demagogy and the inference this argument has on the concept of political representation in democracy. Second, I discussed the claim that populism relies on oversimplification of political issues and what this claim reveals about a democratic ideal of informed and politically responsible voter. Third criticism deals with anti-pluralist character of populist politics, which, I will argue, can also be extended and applied to the concept of popular sovereignty itself. By discussing the inadequacies of populist solutions we are offered a glimpse into cracks within the three pillars of representative democracy - the concept of political representation, the ideal of informed voter and the idea of popular sovereignty. In the second part I look more closely at the relationship between populism and representative democracy. I rely on

\footnotetext{
For a defense of a similar position in Croatian political science, see: Šalaj and Grbeša, 2017;
} 2018. 
the insights from the first part of the article to explore this relationship by discussing different institutional restraints on the will of the majority and how populism redescribes these restraints as anti-democratic and elitist barriers to popular will. Finally, I discuss the prevailing view that sees populism as a phenomenon arising from the tension that exist between liberal and democratic principles within representative democracy and offer an alternative framework for understanding the relationship between populism and democracy.

\section{What is wrong with populism?}

\section{Populism as demagoguery}

A comprehensive study published by the Center for European Studies and the Konrad Adenauer Stiftung on the rise of populism in Europe bears the title Exposing the Demagogues (Grabow and Hartleb, 2013). What this title implies is a well-established argument: populists are modern demagogues who, in their quest for political power, are ready to say whatever voters want to hear without ever planning to deliver on their promises once they come into power. Not only are populists involved in "various forms of political pandering", but, as true demagogues, they advocate "irresponsible policies" that often rely on xenophobic, anti-intellectual and exclusionary political rhetoric (Müller, 2016: 15). Populists, the argument goes, are political conmen who, in their bid for power, exploit public resentment towards political, economic and intellectual elites by presenting themselves as true representatives of the will of the people. However, as one of the best-known novels written about populism - The Wonderful Wizard of $\mathrm{Oz}$ - warns us, there is no wizard at all, just a trickster hiding behind the curtain. The toxic rhetoric used by populists is nothing more than a ploy to gain public support and justify illiberal and exclusionary policy solutions.

In many cases, this is a fair description of populist politics. However, it is worth noting that this criticism rests on a presumption of a widespread public resentment against the perceived elites that populists are able to exploit. What political theorists often point out is that the rise of populism is fueled by the crisis of political representation. It is because voters feel that their interests are neglected by their elected representatives that they turn to populist politicians and movements. As Yascha Mounk argues: "Elected by the people to represent their views, legislators have become increasingly insulated from the popular will" (Mounk, 2018: 77). When discussing the causes of the rise in populism in contemporary liberal democracies, Francisco Panizza recognizes three main causes (Panizza, 2005). First, when a political or social crisis is inadequately addressed or is left unresolved it leaves the impression among the voters that the ruling elite is unable or unwilling to tackle serious political challenges. The global economic crisis of 2008 or the EU's recent immigration crisis are good examples for events that prepared a fertile ground for populist demagogues. The second cause, Panizza argues, can be found in the exhaustion of dominant political traditions and the solutions they are offering. This has certainly been the case with numerous social democratic parties in Europe struggling to find adequate solutions for growing social inequality, the decrease in blue-collar jobs and the rising public debt. Unsurprisingly, many working-class voters that traditionally supported the social democratic option are now turning to populist parties. The third cause of rising populism is to be found in deep changing processes - such as globalization or automation - that 
lead to the loss of manufacturing jobs, the redundancy of unskilled workers and the general disruption in the economy and in social life.

In each of these three instances, there is a crisis of representation where elected officials and traditional political parties are perceived to be working against the interest of the majority of people by protecting the interest of the rich and influential few. This suggests that mainstream politicians are also demagogues: they told the voters what they wanted to hear to get into power, but once in power they act against the interest of those who elected them. We can assume that to get into power, politicians have to win the support of the majority of voters and therefore that they inevitably have to say what voters want to hear, but their inability or unwillingness to deliver what they promised is what leads to the crisis of representation and a strengthening of populism. Here, then, lies the irony: what gives rise to populist demagogues are mainstream demagogues. Populism finds fertile ground when elected representatives disappoint their voters by failing to deliver what they promised. The success of populists' condemnation of corrupt and incompetent political elites and their bid as a "corrective" to liberal democracy rests on the idea that mainstream elites have become too remote from the people they are supposed to represent (Müller, 2016: 57). If we take this argument a step further we can conclude that the discrepancy between what is promised and what is delivered to the voters is a permanent feature of representative democracy. This is what Pierre Rosanvallon had in mind when he argues that "democracy suffers from a permanent crisis of representation" (Rosanvallon, 2006: 91). ${ }^{2}$ In democracy there will always be, to a smaller or larger extent, a divergence between what was promised and what was achieved. What the rise of populism reveals then, is that the core pillar of representative democracy - the idea of political representation - is often followed by its evil twin: demagogy. The critics of populism point out that the success of populist agenda frequently relies on shameless demagogy, but it is worth noting that by this very logic political representation provides a fertile soil for demagogues. Hence, the dangers of populist politics are the dangers that are inherent in representative democracy.

The criticism of populism as a form of demagoguery offers us two important insights. First, that populist demagoguery goes hand in hand with mainstream demagoguery. Or to be more precise, it is the broken promises of mainstream demagogues that drives the voters to give their support to populist demagogues. When political scientists try to explain the reasons for the recent rise in support for populists, what they usually come up with is a list of unresolved political and social problems: a decline in living standards and a lack of job opportunities, especially for younger generations; rising social inequality; a rise in tax breaks and tax avoidance by wealthy corporations; a surge in the cost of housing, higher education and health services; a growth of public debt and inconsistent immigration policies. Unsurprisingly, this results in a sharp decrease in the trust in governments and democratically elected representatives (Eatwell and Goodwin, 2018; Mounk, 2018; Miller, 2018). As a result, there is growing support for populist politicians who condemn the corrupt governing elites and claim to be the true representatives of people's interests. There is a parasitism at play here: the success of populist demagogues depends, in the large part, on the failures of mainstream demagogues. ${ }^{3}$

\footnotetext{
2 A similar argument is put forward by James Miller: "the democratic project... is inherently unstable" (Miller, 2018: 10).

3 For a description of a relationship between constitutional democracy and populism as a parasitic one, see: Arditi, 2007.
} 
The second insight is that the problem of demagoguery in democracy is something that arises from the idea of political representation itself. The logic of democratic representation dictates that to win power one has to win public support. Using demagoguery - either in its mainstream or populist guise - is often a successful strategy in ensuring that support. Hence, the use of demagoguery as a political strategy is not endemic to populism, but inherent to representative democracy. This is the reason why the rhetorical attacks that mainstream politicians and populists launch at each other are often about who actually represents the true interests of the people. Each side depicts their opponents as con artists hiding behind the mask of representation while, in truth, pursuing their own private interests that are directly opposed to the welfare of the citizens. Often, unfortunately, both sides are correct in their assessment of their political opponents. Within the context of representative democracy, demagoguery is not an anomaly or a warning sign that democracy is going off the rails, but a permanent negative feature of political representation and democratic electoral process. Hence, the valid criticism of populist politics - that it is a form of demagoguery - also reveals the inherent problem with representative democracy itself.

\section{Populism as simplification of politics}

The second accusation put forward against populism is that populists not only say what voters want to hear, but also simplify the political language, thus transforming it in a dangerous way. What they offer to the public is a simplified view of politics in which scheming elites conspire against the interests of the majority. In their version of the world complex political and social challenges always have simple and straightforward solutions and the diversity of voters' interests and values is buried under the idea of a homogenous will of the people.

When discussing populist strategies, Rosanvallon talks about three different levels of simplification (Rosanvallon, 2011). First, there is the simplification of policy challenges and solutions. Populists tend to present complex issues such as immigration, climate change, economic stability or security vs. privacy in the simplest terms and offer uncomplicated solutions to these issues. These solutions often show disregard for scientific or expert opinion. Additionally, when presenting their policies, they often exploit existing prejudices or xenophobic and exclusionary sentiments. Talking about "the oversimplification of policy challenges", Müller gives an example of promotional posters by Front National in France claiming that "Two Million Unemployed Is Two Million Immigrants Too Many!" (Müller, 2016: 27, 17). Further examples would be the claims of the former US President Donald Trump that health care reform is simple or that building a wall between the US and Mexico is an easy solution to the problem of illegal immigration. The second strategy of simplification depicts politics as a Manichean world divided between corrupt, self-serving elites and honest common people interested in the public good. The complexity of power relations that exists between different classes, social groups and interest groups is replaced by a simple us vs. them worldview. The third type of simplification that populists rely on is talking about people's will as a homogenous concept where all the diversity of opinions, attitudes and values that exists in a democratic society is replaced by a congruent vox populi. Furthermore, populists claim not only that there is such a thing as a single will of the people, but that their own political agenda best represents that single will. All three levels of simplification, as Rosanvallon points 
out, diminish our public discourse and turn citizens against each other, transforming the cooperative process of collective decision-making into an antagonistic friend vs. enemy political framework (Rosanvallon, 2011).

Rosanvallon's criticism of populism is justified. However, for this line of argument to work, we have to assume that there is an audience that finds convincing the simplified view of politics that populists are peddling. This is what Mudde and Kaltwasser call the supply and demand problem: it is not enough that we have populists trying to distort our political reality by simplified re-descriptions; we also need citizens who embrace these re-descriptions. As Mudde and Kaltwasser argue: "to explain the success (and failure) of populist actors one has to take into account both the demand side and the supply side of populist politics" (Mudde i Kaltwaser, 2017: 97). Hence, the danger that the populist strategy of simplification will lead to the impoverishment of our public discourse becomes real only when enough voters embrace this kind of rhetoric. Let me illustrate this by discussing populists' use of the Manichean "us vs. them" strategy. ${ }^{4}$ When populists offer such a simplified worldview, it only becomes politically relevant when enough of the voters start subscribing to this worldview. What then becomes the main question is this: How does the crisis of representation, followed by fear and resentment against those in power lead informed voters to accept the populist worldview? I, as a voter might be convinced that some of the political elite works against the interests of the majority of citizens, but it does not follow from this that voters will necessarily embrace the simplified Manichean worldview. Alternative responses to this sense of betrayal can range from political apathy to activism, political mobilization or a need for a deeper analysis and understanding of the problem. The crisis of representation does not inevitably lead to support for populist agenda. For that to happen there has to be enough citizens convinced by the "us vs. them" explanation of our political world. The logic of this argument applies not only to the "us vs. them" simplification strategy, but also to the oversimplification of policy solutions and the idea of a single will of the people. In all three instances, the populists' supply of simplified political explanations and solutions has to be met with a demand for such explanations and solutions.

Therefore, following the logic of the supply and demand argument, we must either 1) explain how well-informed and politically responsible voters are transformed into gullible voters who embrace this kind of simplified view of politics or 2) question how well-informed and politically responsible these voters were in the first place. In his influential study of populism, Mounk clearly embraces the second option: "voters do not like to think that the world is complicated. They certainly do not like to be told that there is no immediate answer to their problems. Faced with politicians who seem to be less and less able to govern an increasingly complex world, many are increasingly willing to vote for anybody who promises a simple solution". That is why, Mounk concludes, "glib, facile solutions stand at the very heart of the populist appeal" (Mounk, 2018: 38). Mounk's depressing view of the average democratic voter's susceptiveness to populists' simplified world-view is supported by a substantial amount of empirical research. Political scientists in the past several decades have consistently shown that the majority of voters in democracies are badly informed and sometimes blatantly ignorant about basic facts regarding policy issues, the workings of political institutions and general information about political and social issues (Converse, 1990; Bartels, 1996; Friedman, 2006; Somin,

\footnotetext{
This argument works of all three levels of simplification that Rosanvallon talks about.
} 
2013; Achen and Bartels, 2017). This, in turn, can lead to a simplified view of political solutions to complex political problems.

What both the empirical studies and the voters' support for the populist strategy of simplification suggest is that one of the basic presumptions on which representative democracy rests - the informed and responsible voter - is a myth. The idea that the majority of citizens participating in democratic elections are well-informed and politically responsible is one of the core pillars of democratic order. The justification of democratic collective decision-making rests on this very idea. However, the justified criticism of populist politics of simplification points not only to the dangers of embracing the populist agenda, but also reveals that our image of a rational, intelligent, well-informed and responsible democratic citizen might be an illusion. If the vast majority of citizens reject the populists' attempts to simplify our political reality, then populist movements are condemned to exist on the fringes of a stable democratic society. The fact that the populist strategy of simplification is proving to be a successful way to attract voters in both old and new democracies has a sobering effect on our unrealistic vision of the average democratic voter. Again, looking critically at populism results in an uncomfortable insight into one of the central assumptions of representative democracy.

\section{Populism as anti-pluralism}

The third criticism I want to discuss addresses the populist claim that their voice is the voice of the people and that the solutions they offer are the embodiment of the true will of the people. Not only does this claim, as Rosanvallon points out, rest on a simplified view of a democratic public, but its implications are profoundly anti-pluralist and exclusionary. It is this claim that Müller finds to be the most dangerous aspect of populist politics because it rests on the deep anti-pluralistic assumption that people should be thought of as one. "The core claim of populism", warns Müller, "is thus a moralized form of anti-pluralism" (Müller, 2016: 23). When we describe the concept of people as a homogenous whole, what follows is that those who disagree with the will of the majority can be excluded from that concept. The next step for populists, who present themselves as representatives of the true voice of the people, is to exclude all those who disagree with their politics as not being "a proper part of the people" (ibid.: 9) or worse, as the enemy of the people. This, as Müller points out, is "an exclusionary form of identity politics" (ibid.) where the core value central to identity politics - that of inclusion - is inverted on its head.

Canovan explains how populists exploit the ambiguity in the concept of "the people". We can think of the concept of "the people", Canovan argues, in three distinct ways:

- people as a whole-body politic

- people as an ethno-cultural community

- people as common people / as plebs (Canovan, 2005; see also: Canovan, 2004).

The maneuver that populist use in their praise of the people and the condemnation of the corrupt elites is to equate the first conception - people as a whole - to the third conception - people as simple, uncorrupted people. (in the case of nationalist populism, all 3 conceptions are equated). This inevitably leads to the politics of exclusion where those who disagree with the populist worldview - let's say the liberal academic elite - are not really part of the real people. People here are defined as a 
moral rather than a demographic category. Canovan's argument is supported by Roger Eatwell and Matthew Goodwin, who point out that populism's core claims are based on a stark contrast between "corrupt and distant elites" and their own "attempt to make the popular will heard and acted on" by defending "the interests of the plain, ordinary people" (Eatwell and Goodwill, 2018: 78). The inevitable result is that those who disagree with this simplistic Manichean contrast are branded as either members of the corrupt elite or enablers of such an elite and are, therefore, not part of the people.

I agree that this is a fair criticism of populism, but I believe the problem cuts deeper than Müller, Eatwell, Goodwin or even Canovan suggest. This criticism questions the coherence of one of the core ideas of representative democracy - that of popular sovereignty. The concept of the people as a body politic, the concept on which the idea of popular sovereignty is based upon, is itself anti-pluralist and exclusionary. This becomes clearer if we look at the idea of popular sovereignty within the context of representative democracy as an answer to two distinct questions. The first question is: who is the true source of political authority? The second one is: who rules and for whose benefit? The answer to the first question is: the people and to the second one: the representatives of the people for the benefit of the people. However, if we look at these answers more closely, we can see that in both cases we operate with the definition of the people as a homogenous entity whose individual members have identical interests and concerns. Our answers inevitably led us into the trap of exclusion. Therefore, unless we subscribe to the Rousseauan anti-pluralist ideal of volonté générale, it becomes clear that we are talking about the concept of the people in a meta-political, symbolic kind of way. This is what Jürgen Habermas meant when he said that the idea of the single, homogeneous, authentic people is a fantasy, and that people can only appear in plural (Habermas, 1996). The moment we start thinking of the people as a homogenous whole - that is in anti-pluralist terms - we embrace some form of the politics of exclusion.

The same logic applies when answering the second question: who rules and for whose benefit? Here, we assume that a functioning representative democracy protects the interest of the people by defending, balancing, and compromising between the interests of different social groups - people in plural - rather than the people as a homogeneous whole. Very rarely do governments have a chance to introduce political solutions and public policies that benefit each and every citizen equally. Here again, the claim that the government represents the interest of the people is a symbolic statement because in most cases it is impossible to promote the interests of all the people or people as a whole. In answering this second question, Habermas's insight rings even more true: people can only appear in plural. Populists, in that sense, are consistent: catering for the interest of the (true) people inevitably entails excluding some parts of the population from the people.

More concretely, the process of exclusion in representative democracy manifest itself in two different ways. First, there is a membership exclusion, i.e. demos is defined, first and foremost, by defining who is in and who is out. Second is a decision-making exclusion where the will of the majority is described as the will of the people, while that of the minority is disregarded. An obvious historical example of membership exclusion, one that Müller cites, is the Jacobins and their politics of terror, which invoked the will of the people to justify the prosecution of their ideological opponents as the enemies of the people (Müller, 2016: 59-60). However, Müller does not mention another historical example of a democratic revolution that 
also invoked the concept of the people in an exclusionary manner. Here, of course, I am referring to the American Revolution and the Republic's Founding Fathers' opening phrase of the Declaration of the Independence: "We the People". This has always been perceived in a much more positive light than the terror of the French Revolution. The US concept of "We the People" not only excluded Native-Americans and black slaves, but also the British loyalists who opposed the independence of the colonies. In fact, sixty thousand of them had their land confiscated and were forced to move to Canada or England. (This is how Thomas Paine got his house and land from the newly established US government.) This type of exclusion was not only a feature of the American or the French Rrepublic but, as Mounk acknowledges, nation building in Europe in the $18^{\text {th }}$ and $19^{\text {th }}$ centuries "nearly always took the form of a hankering for ethnic purity as well as democracy" (Mounk, 2018: 163). I do not want to suggest that representative democracies are inevitably exclusionary, but historical records show that the use of the concept of the people in democracies, as a way to justify excluding certain groups of people from membership, is not unique to populists. Rather, my argument is that invoking the ideal of the people as a homogenous whole - in its populist, republican, liberal or conservative guise - is the first step in the politics of exclusion.

The second type of exclusion in democracies - decision-making exclusion - is also not unique to populism. The core assumption of representative democracy is that in free societies citizens will unavoidably disagree not only on policy issues, but also on their understanding of the political community they want to live in. As John Rawls points out in Political Liberalism, pluralism "is the normal result of the exercise of human reason within the framework of the free institutions of a constitutional democratic regime" (Rawls, 1993: xviii). That is why whenever somewhere nearly 100 percent of voters elect a candidate or agree on an answer to a referendum question, we rightly assume that the voting process was rigged and that we are talking about an autocracy rather than a democracy. In representative democracy the will of the people is never uniform. However, for procedural reasons we equate the will of the majority with the will of the people. What inevitably follows is that the will of those who are in disagreement with the majority is ignored when defining what the will of the people decided. An obvious recent example to this is the Brexit vote, where out of $72,2 \%$ of the electorate that voted, $51,9 \%$ that voted "yes", was referred later, by both supporters and the opponents of the Brexit, as the true will of the British people.

The criticism of populism as anti-pluralist and exclusionary is on point. However, it is worth noting that populist exclusionary politics arises not from some perverse or corrupt understanding of the concept of people, but that this concept is anti-pluralist in its very nature. Whenever we invoke the idea of the people as a homogenous whole in democracy beyond its symbolic form - as is the case with membership exclusion or decision-making exclusion - we almost inevitably dismiss or discriminate against some of our fellow citizens. Here lies the danger of answering the question "Who rules?" by saying: The people do. This is the reason why Hans Kelsen, in his rejection of Carl Schmitt's idea of the homogenous people as a basis of political order - called the people "a meta-political illusion" (Kelsen, 1981: 22). ${ }^{5}$ It is

5 See also Urbinati, 2017: 44: "powerful myth with which democracy was born... myth that representative system tried to reproduce, in fiction, at the symbolic and indirect level: the myth of the perfect unity of the collective sovereign endowed with a single will"; and Morgan's argument on the logic of popular sovereignty which implies that the people can strive for "the fiction of the People" but should "never reach it" (Morgan, 1988: 90-91). Similarly, in his letter 
this illusion, however, that is one of the constitutive elements of the democratic theory of legitimacy. The very idea of popular sovereignty is not a populist invention, but a core pillar of representative democracy. Populists are only pushing this idea to its logical exclusionary conclusion. Achieving a stable, inclusionary and pluralist representative democracy requires that we curtail the idea of popular sovereignty and refer to it as a symbolic, rather than an operational concept. Once again, the criticism of populism reveals a deep problem with the idea that lies at the heart of representative democracy - that of popular sovereignty.

To sum up, in this part of the paper, I have demonstrated how contemporary criticism of populism leads to the unmasking of the cracks in the three pillars that our understanding of representative democracy stands on - that of representation, responsible voters and popular sovereignty. To refer back to the analogy from the introduction, looking at the vices of the populist Mr. Hyde I illustrated the questionable character traits of democratic Dr. Jekyll. In what follows, I will further explore the relationship between populism and representative democracy.

\section{The relationship between populism and representative democracy}

If my central argument is correct - that populism is a negative manifestation of democracy's own myths - does it make sense to contrast representative democracy and populism in such stark terms? If the challenges of demagoguery, ignorance and irresponsibility of voters and the exclusionary nature of popular sovereignty are permanent fellow travelers of representative democracy, why did populism have to surge to reveal these shortcomings?

The answer lies in the institutional mechanisms that representative democracies have put in place to avoid these challenges. It is through these mechanisms that democracy tries to protect itself from its own myths. Here I am referring to mechanisms such as institutional checks and balances, an independent media, expert policymakers, political parties and policies of minority representation and inclusion. The main purpose of the system of checks and balances (especially the independent judiciary) is to prevent a concentration of political power in one branch of a government, but also to ensure pluralism and the protection of the rights of all citizens by curtailing the will of the majority. Similarly, political parties are not only a mechanism to mobilize and politically organize voters, but also to ensure responsible governance by providing viable alternatives to current officeholders. They represent the plurality of different interests that exist within the society and filter citizens' demands into coherent policies. ${ }^{6}$ The role of the independent media is to provide information necessary for citizens to make rational and informed decisions, but also to unmask demagoguery and give a platform to the plurality of voices in a democratic society. The involvement of experts in designing public policies is even more explicitly aimed at rejecting simplified, exclusionary or scientifically unfounded political solutions advocated by demagogues and embraced by uninformed or ir-

to Robert Michels, Max Weber claimed "Such notions as 'will of the people' and 'genuine will of the people' have long since ceased to exist for me; they are fictions" (see: Miller, 2018: 168).

6 As Miller argues: "Throughout Europe, the rise of the party system contributed to a gradual process of democratization, involving the slow expansion of the franchise, the institutionalization of civil liberties, and the emergence of a central government accountable to voters, through either a parliament or a direct vote" (Miller, 2018: 157). 
responsible voters. Specifically, policies addressing the political and social inclusion of minorities - such as quotas for minority representatives or different multicultural policies - address both the membership and decision-making exclusion aspects of popular sovereignty.

It is worth noting that all of these mechanisms are undemocratic, but not necessarily anti-democratic. What I mean is that they are designed to curtail and limit the will of the majority, therefore, they are undemocratic. However, that does not mean that they are anti-democratic, i.e. intended to work against the interests and the welfare of the majority of citizens. Actually, a functioning and stable representative democracy uses these undemocratic mechanisms for the benefit of its citizens and the maintenance of democracy itself. Here we can draw a parallel between representative democracy and the free market as an efficient system of property exchange. A completely unregulated market would collapse on itself by creating monopolies, unsustainable levels of social inequalities, overproduction, non-provision of public goods, lack of consumer protection, negative externalities, etc. Similarly, representative democracy has to rely on the abovementioned undemocratic mechanisms to ensure its own survival. A democracy that puts no limits on the will of the majority would quickly stop being democratic. As Nadia Urbinati convincingly argues, a democratic system that would allow the majority to exclude political options with minority support from political competition, "that infringes basic political rights - especially the rights crucial for forming opinions and judgments, expressing dissents, and changing views - and that systematically precludes the possibility of the formation of the new majorities is not a democracy at all" (Urbinati, 2019: 10).

That being said, it is possible that some of these undemocratic mechanisms that were initially designed to make representative democracies both stable and truly representative became distorted and utilized in an anti-democratic way. This happens when there is a shift from policies designed for the benefit and welfare of the citizens to policies that promote special interests at the expense of everyone else within the political community. Authors like Laclau and Rancière describe this process as a transformation of representative democracy to elective oligarchy (Laclau, 2007; Rancière, 2006). In the glory days of representative democracy - from the post-war period to the 70's - the abovementioned undemocratic mechanisms were, in a large part, used in a way that led to an increase in economic prosperity, a decrease in social inequality and a rise in equality of opportunity, living standards and better and more inclusive public services. The general success of these policies gave legitimacy to both political elites and experts, as well as validity to their claim that they represent the interest of the people. Eatwell and Goodwin refer to this period as the Golden Age of Capitalism "when prosperity was widely enjoyed" (Eatwell \& Goodwin, 2018: 189), while Mounk describes it as "the period of democratic stability" when "most citizens enjoyed a rapid increase in their living standards" (Mounk, 2018: 15). From the 1970's on, however, we can witness how undemocratic limits on the will of the majority slowly transform into an anti-democratic promotion of oligarchic interests at the expense of the public's welfare. ${ }^{7}$ Political parties became more dependent on big corporate donors and powerful interest lobbies. Laws and court rulings

\footnotetext{
As John Dunn claims: "For much of the post-war period across North America, Western Europe, and Japan, it saw protracted periods of relative felicity as economies grew, welfare systems were extended, and the lives of most citizens visibly improved along with them. By 2000 at the latest that was no longer clearly the case, the rewards of residual growth were shared far more inequitably" (Dunn, 2018: 177)
} 
reflected oligarchic agenda through policies of deregulation, privatization, tax cuts and cuts in public spending. The mainstream media became more ideologically biased and often focused on promoting the interests of big money. All of this resulted in an increase in economic and social inequality, followed by a decrease in equality of opportunity and social mobility, a deepening of political polarization and elected officials' further detachment from their constituents.

Populism thrives on the failures of representative democracy. Populists will point out that corrupt politicians and technocratic elites, by disregarding the will of the people (i.e. will of the majority), inevitably also disregard the interest of the people. What makes this claim more or less convincing depends, in large part, on how successful the undemocratic mechanisms are in actually ensuring the welfare of the majority of citizens. As Mounk points out, for many citizens in democratic societies the support for liberal democratic institutions in large part depends not on the abstract ideals of justice, but on the outcomes these institutions deliver (Mounk, 2018: 131). However, populists go a step further: their core argument is that undemocratic mechanisms designed to limit the popular will are intrinsically anti-democratic. By invoking a minimalist concept of democracy where the only criteria for evaluating a certain policy or a political decision as correct and just is to see if it corresponds to the will of the majority, populists can claim that decisions made by the elites professional politicians, judges, policy experts and technocrats - are by definition anti-democratic. "In light of the populist ideal of the people ruling themselves", Amy Gutmann points out, "any constraints on popular rule are undemocratic even if, all things considered, the constraints are justified" (Gutmann, 2007: 532). The populist argument is not about outcomes, i.e. assessing if check and balances, political parties, mainstream media or experts designing public policies are actually benefiting citizens. Rather, it is about the very nature of decision-making: any institution or practice designed to limit the will of the people is, at its core, anti-democratic. Therefore, for populists, there is no point in trying to restore undemocratic mechanisms that limit the will of the people in a way that would promote the interests of all citizens. Their mission is not to restore representative democracy by curtailing the oligarchic influence on collective decision-making process. On the contrary, populism's goal is to destroy any undemocratic constraints on the sovereignty of the people by introducing the policies that represent the will of the 'true' people. Populists are more than willing to pay the price of achieving this goal: the emergence of the dark side of democracy through shameless demagoguery, anti-intellectual worship of the wisdom of the 'common man' and embracing the anti-pluralist and exclusionary concept of the people.

The evidence for this kind of populist strategy has been well documented by theorists like Müller (2016) and Urbinati (2019) in their analysis of populists in power. Once populist movements manage to win elections, they act quickly to dismantle any institutional limits on the democratic will of the 'true' people. The checks and balances system is eroded by limiting the powers of the independent judiciary or by packing the courts with judges known to be loyal to the new government. Parliamentary opposition is demonized as traitors to the people. The independent media becomes 'fake news', while state-run media is put under the control of editors and journalists sympathetic to the populist government. The opinions of experts are dismissed as biased and disconnected from the will of the people. The politics of compromise and balancing of different interests that exist within the society are abandoned for the 'true' representation of the people's will embodied in the deci- 
sions of a populist leader. There is an abundance of examples for this kind of populist strategy from both the left - such as Hugo Chavez in Venezuela - and the right - such as Berlusconi in Italy, Fidesz in Hungary, PIS in Poland or Trump in the USA.

The populist strategy of equating undemocratic constraints on the popular will with anti-democratic dangers of representative democracy also explains why it is often futile to try and convince disappointed citizens with populist sympathies to rely on the authority of experts - courts, scientists, policy experts, professional journalists, etc. - when trying to make informed political decisions. From a populist perspective, the authority of these experts is a priori problematic because their undemocratic role in the public sphere is to question and limit the will of the people. Therefore, whatever agenda these experts are promoting can only lead to anti-democratic outcomes. Their authority is suspect not because of their lack of real expertise, but because of their motives: their aim is to promote elitist and oligarchic interests at the expense of the interest of the people. Within this context, invoking policy expertise as a solution to the representation crisis can actually help populists - as the public outcry against experts in both the period after the 2008 economic crisis, debates on Brexit or current opposition to Covid vaccines suggest. The expert policymakers and mainstream opinion-makers can now be seen - as populists are quick to point out - as part of the problem, not as part of the solution. Consequently, experts' criticism of populist rhetoric and policies as demagogy, as a dangerous simplification of complex political and social issues and as politics of exclusion can be easily dismissed as unfounded and biased. The attack on the elites in populist rhetoric serves a dual purpose: first, to mobilize popular support by identifying the political, economic, intellectual and cultural elites as oligarchic villains and, second, to deflect any criticism of populist agenda as a part of an elitist ploy to deprive the people of their rule. This can help explain the paradox at the heart of populist politics: responding to the elective oligarchy's anti-democratic disregard of people's interest by relying on an anti-democratic exclusion of all those who are critical of populist goals. As Urbinati points out: "populism expresses two things at the same time: the denunciation of exclusion, on the one hand, and the constitution of a strategy of inclusion by means of exclusion (of the establishment)" (Urbinati, 2019: 33). This negative description of populist agenda holds regardless of our definition of populism (as an ideology, political logic, rhetoric or a mere strategy).

Based on these insights, what kind of conclusions can we draw on the relationship between populism and representative democracy? One way to look at this relationship is through the lens of the underlying tension between the liberal and democratic elements that constitute both the normative and the institutional structure of constitutional democracies. This two-strand model of democracy is advocated by Chantal Mouffe in The Democratic Paradox when she argues: "On one side we have the liberal tradition constituted by the rule of law, the defense of human rights and the respect of individual liberty; on the other the democratic tradition whose main ideas are those of equality, identity between governing and governed and popular sovereignty. There is no necessary relation between those two distinct traditions but only a contingent historical articulation" (Mouffe, 2000: 2). In a later text, she talks about the "necessary tension which exists between the logic of liberalism [individual liberty and pluralism] and the logic of democracy [popular sovereignty and equality], and the impossibility of a final reconciliation" (Mouffe, 2005: 53). A similar argument is put forward by Steven Levistky and Daniel Ziblatt: "An overreliance of gatekeeping is, in itself, undemocratic - it can create a world of party bosses who 
ignore the rank and file and fail to represent the people. But an overreliance on the 'will of the people' can also be dangerous, for it can lead to the election of a demagogue who threatened democracy itself". Their conclusion is that "there is no escape from this tension. There are always trade-offs" (Levitsky and Ziblatt, 2018: 34). This two-strand view rests on a presupposition that there is an integral and unresolvable tension between the liberal and democratic values at the heart of representative democracy. The best we can hope to achieve is a stable balancing act that manages to restrain the excesses of popular will through undemocratic institutional mechanisms without sacrificing the interest of the people in the process. Populism grows in strength when this balancing act fails, i.e. when liberal restraints on popular will result in the promotion of narrow oligarchic interests at the expense of the interest of the majority. In this view, populism can have a corrective role by restoring the balance by strengthening the democratic side. The danger is that populism can tip the balance too far to the democratic side, which can result in anti-pluralist and exclusionary politics. ${ }^{8}$

There is, however, another way we can understand the relationship between populism and the ideal of representative democracy. The argument that I have put forward in this article is that democracy is haunted by certain vulnerabilities that are imbedded in its very core: political representation invoking demagoguery; voters embracing ill informed, irresponsible or discriminatory political solutions; and the realization of the ideal of popular sovereignty leading to exclusionary and anti-pluralist outcomes. If left unrestrained through different institutional mechanism - rule of law, checks and balances, political parties, expert policy making, independent media - these democratic vulnerabilities will abolish democracy itself. In this reading, these undemocratic restraints or gatekeepers, are not liberal impositions on the true spirit of democracy, but necessary mechanisms for democracy's survival. It would be naïve to think that these mechanisms can never be abused for anti-democratic purposes, i.e. for promoting oligarchic interests or specific interest groups at the expense of the good of the majority. After all, that is exactly a tendency we have witnessed in many democratic societies in the last half a century. However, that does not mean that the liberal elements took a precedence over democratic elements in liberal-democratic regimes, but that liberal gatekeeping has failed in its task by distorting the necessary and justified undemocratic restraints on popular will into anti-democratic disregard for public good.

How should we evaluate populism then? Populism can help us reveal these democratic vulnerabilities in the same way that Mr. Hyde reveals the repressed nature of Dr. Jekyll. However, populism is neither the corrective, not the adequate cure for stopping the transformation of representative democracy to elective oligarchy. A reason for this is that populism equates undemocratic restraints on popular will with the anti-democratic interest of the elites to exclude the majority of citizens from a meaningful decision-making process. By rejecting undemocratic restraints, populism embraces the demagoguery, anti-pluralism and exclusionary politics of the uninhibited Mr. Hyde of democracy. The populist solution to saving democracy results, in the best-case scenario, in an anti-pluralist tyranny of the majority and, in the worst and more likely scenario, in an autocratic concentration of power in

8 For criticism of this two-strain model of democracy, see Canovan's essay "Trust the People!" where she argues that this model "seems to imply that however weak populists may be as liberals, they do get full marks on the democracy section of the paper" (Canovan 1999: 8). See also: Urbinati, 2019. 
the hand of one party and one leader posing as an embodiment of the true will of the people. Once in power, populist leaders and movements prove that if the abovementioned democratic vulnerabilities are allowed to blossom without any restraints, democracy collapses on itself. The populist cure for the oligarchic threat to democracy results, paradoxically, in the destruction of democracy. Therefore, on this view of democratic ethos there is no such thing as an illiberal democracy or oligarchic liberalism. If we accept that the core principle of liberal philosophy is treating all persons as free and equal then the promotion of narrow oligarchic and elitist interests while disregarding the interests and welfare of the rest of the citizens directly violates this principle. Similarly, a populist democracy that abandons liberal constraints on popular will inevitably stops being a real democracy once it embraces the politics of exclusion by identifying its supporters as the true people and its critics as the enemies of the people. Here, in conclusion, we have an answer to the question of what is wrong with populism. Populism is the face of the dark side of democracy that, if unrestrained, brings about democracy's downfall. 


\section{References}

Achen, C. H., and Bartels, L. M. (2017). Democracy for Realists: Why Elections Do Not Produce Responsive Government. Princeton: Princeton University Press.

Arditi, B. (2007). Politics on the Edges of Liberalism: Difference, Populism, Revolution, Agitation. Edinburgh: Edinburgh University Press.

Bartels, L. (1996). Uninformed Voters: Information Effects in Presidential Elections. American Political Science Review, 40(1), 194-230. https://doi.org/10.2307/2111700

Canovan, M. (1999). Trust the People! Populism and the Two Faces of Democracy. Political Studies, 47(1), 2-16. https://doi.org/10.1111/1467-9248.00184

Canovan, M. (2004). Populism for political theorists? Journal of Political Ideologies, 9(3). 241-252. https://doi.org/10.1080/1356931042000263500

Canovan, M. (2005). The People. Cambridge: Polity.

Converse, P. E. (1990). Popular Representation and the Distribution of Information, in: J. F. Ferejohn and J. H. Kuklinski (eds.), Information and Democratic Processes (pp. 369-388). Urbana: University of Illinois Press.

Dunn, J. (2018). Setting the People Free: The Story of Democracy. Princeton: Princeton University Press.

Eatwell, R. and Goodwin, M. (2018). National Populism: The Revolt Against Liberal Democracy. London: Penguin Random House.

Friedman, J. (2006). Democratic Competence in Normative and Positive Theory: Neglected Implications of 'The Nature of Belief Systems in Mass Publics'. Critical Review, 18(1-3), i-xliii. https://doi.org/10.1080/08913810608443649

Grabow, K. and Hartleb, F. (2013). Exposing the Demagogues. Brussels: Centre for European Studies.

Gutmann, A. (2007). Democracy. In: R.E. Goodin, P. Pettit and T. Pogge (eds.), A Companion to Contemporary Political Philosophy (pp. 521-531). Malden: Blackwell Publishing.

Habermas, J. (1996). Between Fact and Norms: Contributions to a Discourse Theory of Law and Democracy. Cambridge: The MIT Press.

Judis, J. B. (2016). The Populist Explosion. New York Columbia Global Reports.

Kazin, M. (1995). The Populist Persuasion: An American History. Ithaca: Cornell University Press.

Kelsen, H. (1981). Vom Wesen und Wert der Demokratie. Aalen: Scientia.

Laclau, E., and Mouffe, C. (1985). Hegemony and Socialist Strategy: Towards a Radical Democratic Politics. London: Verso.

Laclau, E. (2005a). On Populist Reason. London: Verso.

Laclau, E. (2005b). Populism: What's in a Name? In: F. Panizza (ed.), Populism and the Mirror of Democracy (pp. 32-49). London and New York: Verso.

Laclau, E. (2007). On Populist Reason. London: Verso.

Lasch, C. (1996). The Revolt of the Elites and the Betrayal of Democracy. New York and London: W. W. Norton.

Levitsky, S. and Ziblatt, D. (2018). How Democracies Die. New York: Crown.

Miller, J. (2018). Can Democracy Work? New York: Farrar, Straus and Giroux. 
Morgan, E. S. (1988). Inventing the People: The Rise of Popular Sovereignty in England and America. New York: Norton.

Mouffe, C. (2005). The 'End of Politics' and the Challenge of Right-wing Populism. In: F. Panizza (ed.), Populism and the Mirror of Democracy (pp. 50-71). London and New York: Verso.

Mouffe. C. (2000). The Democratic Paradox. London: Verso.

Mounk, Y. (2018). The People vs. Democracy: Why Our Freedom is in Danger and How to Save It. Cambridge: Harvard University Press.

Mudde, C., and Kaltwasser, C. R. (2017). Populism: A Very Short Introduction. Oxford: Oxford University Press.

Müller, J. W. (2016). What is Populism? Philadelphia: University of Pennsylvania Press.

Panizza, F. (2005). Introduction: Populism and the Mirror of Democracy, In: F. Panizza (ed.), Populism and the Mirror of Democracy (pp. 1-31). London and New York: Verso.

Rancière, J. (2006). Hatred of Democracy. London: Verso.

Rawls, J. (1993). Political Liberalism. New York: Columbia University Press.

Rosanvallon, P. (2011). Penser le Popuulsim. La Vie des idées. September 9. http:// www.laviedesidees.fr/Penser-le-populisme.html

Rosanvallon, P. (2006). Revolutionary Democracy. In: S. Moyn (ed.): Democracy Past and Future (pp. 79-97). New York: Columbia University Press.

Rosanvallon, P. (2008). Counter-Democracy: Politics in an Age of Distrust. Cambridge: Cambridge University Press.

Šalaj, B., And Grbeša, M. (2017). Što je populizam i kako ga istraživati? Društvena istraživanja, 26(3), 321-340. https://doi.org/10.5559/di.26.3.01

Šalaj, B. and Grbeša, M. (2018). Dobar, loš ili zao? Populizam u Hrvatskoj. Zagreb: TIM press.

Somin, Ilya. (2013). Democracy and Political Ignorance. Stanford: Stanford University Press.

Urbinati, N. (2019). Me The People: How Populism Transforms Democracy. Cambridge: Harvard University Press. 


\section{Što ne valja s populizmom?}

Sažetak Glavni je cilj ovog članka istražiti odnos između populizma i predstavničke demokracije. Rad je podijeljen u dva dijela. U prvom dijelu rad nudi detaljnu analizu triju kritika populizma i implikacija koje te kritike imaju na naše razumijevanje predstavničke demokracije. Prvo, bavi se argumentom da se populizam neizbježno oslanja na demagogiju i ispituje posljedice koje ovaj argument za koncept političkog predstavljanja u demokraciji. Drugo, raspravlja se o tvrdnji da se populizam oslanja na pretjerano pojednostavljenje političkih pitanja i onome što ta tvrdnja otkriva o demokratskom idealu informiranog i politički odgovornog birača. Treća se kritika bavi antipluralističkim karakterom populističke politike, koja se, tvrdi se u radu, može proširiti i na sam koncept narodne suverenosti. $U$ drugom dijelu, članak se pobliže bavi odnosom populizma i predstavničke demokracije. Oslanjajući se na uvide iz prvog dijela, ispituje se različita institucionalna ograničenja volje većine i kako populizam ta ograničenja redefinira kao antidemokratske i elitističke prepreke narodnoj volji. Konačno, rad propituje prevladavajuće stajalište koje drži da je populizam fenomen koji proizlazi iz napetosti između liberalnih i demokratskih načela unutar predstavničke demokracije te nudi alternativni okvir za razumijevanje odnosa između populizma i demokracije.

Ključne riječi populizam, predstavnička demokracija, demagogija, narodna suverenost, narod

Kako citirati članak / How to cite this article:

Kulenović E. (2021). What is Wrong with Populism? Anali Hrvatskog politološkog društva, 18(1), 325-342. https://doi.org/10.20901/an.18.14 